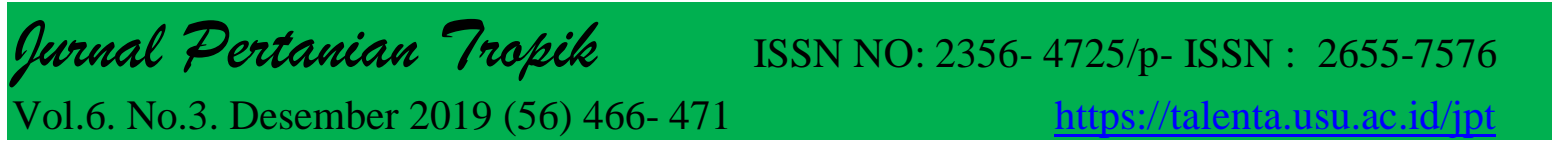

\title{
Identifikasi kromosom hasil cangkok anakan salak Sidempuan (Salacca sumatrana Becc.) di Kecamatan Angkola Barat
}

\section{Identification of chromosomes produced by Sidempuan salak grafted germ (Salacca} sumatrana Becc.) In Angkola Barat District

Meiliana Friska ${ }^{1^{*}}$

${ }^{1}$ Program studi Agroteknologi, Fakultas Pertanian Universitas Graha Nusantara

*Coreesponding author: melianafriska90@gmail.com

\begin{abstract}
Salak Sidimpuan (Salacca sumatrana Becc.) is one of the superior commodities in South Tapanuli Regency. The availability of good quality zalacca varieties, high productivity, resistance to pests and diseases and tolerance to environmental stress are conditions that must be met in the era of agricultural industrialization. For this reason, it is necessary to assemble new superior salacca cultivars to meet the evolving demands of consumers and to anticipate potential cultivation constraints. Zalacca chromosome analysis is expected to be able to produce information about the chromosome composition of these plants, which can then be useful in supporting zalacca breeding. The aim of this study was to obtain the identity of the Salacca Sumatrana Becc. The plant based on the morphological characteristics of chromosomes (number, shape and karyotype of chromosomes). This research was conducted at the Laboratory of Genetics, Faculty of Biology, University of North Sumatra, Medan in April-May 2019. The results of this study indicate that Salak Sidempuan (Salacca sumatrana Becc.) have the number of chromosomes is $2 n=28$, the shape of the chromosome and the karyotype formula was $2 \mathrm{n}=9 \mathrm{~m}+5 \mathrm{sm}$ (9 metacentric chromosomes and 5 submetacentric chromosomes)
\end{abstract}

Keywords: Salak Sidimpuan (Salacca sumaterana Becc.), chromosome, karyotype

\begin{abstract}
ABSTRAK
Salak Sidimpuan (Salacca sumatrana Becc.) merupakan salah satu komoditi unggul di Kabupaten Tapanuli Selatan. Ketersediaan varietas salak unggul bermutu baik, produktivitas tinggi, tahan terhadap hama dan penyakit dantoleran terhadap cekaman lingkungan menjadi syarat yang harus dipenuhi pada era industrialisasi pertanian. Untuk itu perlu dilakukan upaya perakitan kultivar- kultivar salak unggul baru untuk memenuhi permintaan konsumen yang selalu berkembang dan mengantisipasi kendala-kendala budidaya yang potensial. Analisis kromosom tanaman salak diharapkan mampu menghasilkan informasi mengenai susunan kromosom tanaman tersebut, selanjutnya dapat berguna dalam mendukung pemuliaan tanaman salak. Penelitian ini bertujuan mendapatkan identitas tanaman salak Padang Sidempuan (Salacca sumatrana Becc.) berdasarkan sifat morfologi kromosom (jumlah, bentuk dan kariotipe kromosom). Penelitian ini dilaksanakan di Laboratorium Genetika Fakultas Biologi Universitas Sumatera Utara Medan pada bulan April-Mei 2019. Hasil
\end{abstract}


penelitian menunjukkan bahwa tanaman tanaman salak Padang Sidempuan (Salacca sumatrana Becc.) memiliki jumlah kromosom $2 \mathrm{n}=28$, bentuk kromosom dan rumus karyotipe adalah $2 \mathrm{n}=9 \mathrm{~m}+5 \mathrm{sm}$ ( 9 kromosom metasentrik dan 5 kromosom submetasentrik)

Kata Kunci: Salak Sidimpuan (Salacca sumaterana Becc.), kromosom, kariotipe

\section{PENDAHULUAN}

Salak Sidimpuan (Salacca sumatrana Becc.) merupakan salah satu komoditi unggul di Kabupaten Tapanuli Selatan dengan sentra produksi terdapat di Kecamatan Angkola Timur, Angkola Selatan dan Angkola Barat. Salak Sidimpuan merupakan komoditi lokal yang memiliki prospek pengembangan yang baik. Namun, dalam pengembangannya terdapat beberapa kendala yang dihadapi antara lain sistem budidaya tanaman yang masih sederhana, tidak dilakukan pemupukan serta penerapan teknologi bibit yang masih bersifat tradisional.

Varietas salak Padangsidimpuan cukup banyak, yang didasarkan pada karakter buah (bentuk, aroma, rasa serta warna kulit buah) atau lokasi dimana salak ditanam atau dibudidayakan. Pada saat ini terdapat 3 varietas salak sesuai keputusan Menteri Pertanian yaitu salak Padangsidimpuan Merah (SK.No.763/Kpts/TP.240/6/99), Salak Padangsidimpuan Putih (SK.No.764/Kpts/TP.240/6/99) dan salak Sibakua (SK.No.427/Kpts/ TP.240/7 2002) (BPS, 2010).

Upaya perakitan kultivar-kultivar salak unggul perlu dilakukan untuk memenuhi permintaan konsumen yang selalu berkembang dan mengantisipasi kendala-kendala budidaya yang potensial. Jumlah kultivar salak unggul masih relatif terbatas. Ketersediaan kultivar-kultivar unggul baru akan sangat mendukung pengembangan budidaya tanaman salak (Parjanto dkk., 2003).

Peningkatan produktivitas dan mutu salak melalui pemuliaan menghadapi kendala yaitu rendahnya keragaman genetik salak. Identifikasi kromosom tanaman salak diharapkan dapat menghasilkan informasi mengenai susunan kromosom (kariotipe) tanaman salak, selanjutnya dapat berguna dalam mendukung pemuliaan tanaman salak. Bibit salak yang digunakan berasal dari cangkok anakan salak (vegetatif) karena hasil cangkok anakan salak memiliki beberapa kelebihan, yaitu: kualitas buah yang sama dengan induknya, dapat ditentukan bibit salak betina atau jantan, dan waktu berbuah yang lebih cepat.

Dengan demikian, perlunya mempertahankan keberadaan tanaman Salak Sidimpuan (Salacca sumatrana Becc.) sebagai tanaman yang banyak terdapat di daerah Angkola Barat sebagai buah yang memiliki prospek yang tinggi. Karena itu, perlu adanya pelestarian tanaman Salak Sidimpuan dengan mengetahui informasi morfologi dan genetika tanaman, khususnya kromosom.

\section{BAHAN DAN METODE}

\section{Pengambilan bahan.}

Lokasi pengambilan bahan Salak Sidimpuan di Desa Lobulayan Kecamatan Angkola Barat. Bahan diambil dari ujung akar yang meristematis $\pm 5 \mathrm{~mm}$.Ujung akar digunakan sebagai bahan pembuatan sediaan karena ujung akar merupakan organ paling meristem selalu membelah untuk 


\section{Devnal Pertanian Tropile \\ Vol.6. No.3. Desember 2019 (56) 466- 471}

bergerak mencari unsur hara (Setyawan dan Sutikno, 2000). Pemotongan akar salak dilakukan pada pukul 07.30 WIB, 08.00 WIB dan 08.30 WIB.

\section{Pembuatan preparat.}

Pembuatan preparat dalam penelitian ini metode squash (pra perlakuan aquadest selama 24 jam pada suhu $5-10^{\circ} \mathrm{C}$, fiksasi menggunakan larutan Carnoy (6 etanol : 3 kloroform : 1 asam asetat glasial), hidrolisis dengan larutan $\mathrm{HCl} 1 \mathrm{~N}$ selama 10 menit pada suhu ruang, pewarnaan kromosom menggunakan larutan aceto-orcein 1\% selama 1 jam dan pemencetandengan carabahan ditetesi asam asetat $45 \%$ dan ditutup dengan gelas penutup kemudian dipencet (squash) dengan ibu jari. Preparat ini selanjutnya digunakan untuk pengamatan sifat-sifat morfologi kromosom.
ISSN NO: 2356- 4725/p- ISSN : 2655-7576

https://talenta.usu.ac.id/jpt

\section{Pengamatan dan Pemotretan.}

Preparat yang telah diperoleh kemudian diamati dibawah mikroskop dengan menggunakan mikroskop cahaya. Metode ini merupakan modifikasi metode yang dipergunakan oleh Parjanto dkk., (2003).

\section{HASIL DAN PEMBAHASAN}

\section{Jumlah kromosom}

Jumlah kromosom merupakan data yang paling sering digunakan dalam penelitian taksonomi karena pengamatannya yang mudah dilakukan (Pujoarianto, 2001). Untuk menghitung jumlah kromosom dilakukan pengamatan dengan menggunakan mikroskop. Hasil pengamatan kromosom dapat dilihat pada Tabel

Tabel 1. Hasil pengamatan kromosom Salak Sidimpuan

\begin{tabular}{|c|c|c|}
\hline $\begin{array}{c}\begin{array}{c}\text { Waktu pemotongan } \\
\text { akar }\end{array} \\
\end{array}$ & Hasil & Keterangan \\
\hline Pukul 07.30 WIB & & $\begin{array}{l}\text { Kromosom belum terlihat } \\
\text { karena sel belum pecah }\end{array}$ \\
\hline Pukul 08.00 WIB & & $\begin{array}{l}\text { Kromosom terlihat dalam } \\
\text { sel dan berada pada fase } \\
\text { profase }\end{array}$ \\
\hline
\end{tabular}


Pukul 08.30 WIB

Menurut Rindyastuti dan Daryono (2009), lama fase mitosis secara khusus diatur oleh gen dan bervariasi antara spesies yang satu dengan spesies lainnya, antara organ yang satu dengan organ yang lainnya dalam satu spesies, bahkan antara tipe sel satu dengan tipe sel yang lainnya.

Hasil pengamatan kromosom dapat terlihat pada pukul 08.00 WIB dan menunjukkan bahwa tanaman Salak Sidimpuan memiliki jumlah kromosom $2 \mathrm{n}=$ 28. Sewoyo (2008) menyatakan bahwa jumlah kromosom semua individu dari suatu spesies adalah tetap dari generasi ke generasi. Jumlah kromosom salak adalah diploid, yaitu satu pasang kromosom terdiri atas dua set kromosom homolog. Oleh karena itu variasi jumlah set kromosom (ploidi) pada tanaman salak termasuk dalam kelompok euploidi, yaitu keadaan bahwa jumlah kromosom yang diamati dari suatu
Kromosom belum terlihat karena sel belum pecah. Sel masih terlihat menumpuk makluk hidup merupakan kelipatan dari jumlah kromosom dasarnya.

\section{Bentuk kromosom}

Setiap kromosom memiliki sentromer, karena sentromer berfungsi sebagai tempat berpegangannya benangbenang plasma dari spindel atau gelendong inti di waktu pembelahan sel berlangsung. Apabila benang spindel berkontraksi sehingga memendek, maka kromosom bergerak (tertarik) ke arah kutub sel pada fase anafase (Sewoyo, 2007)

Bentuk kromosom dibedakan menjadi 4 macam yaitu metasentrik, submetasentrik, akrosentrik dan telosentrik. Letak sentromer merupakan salah satu sifat morfologi kromosom yang penting dalam identifikasi kromosom. Bentuk kromosom Salak Sidimpuan dapat dilihat pada Tabel 2.

Tabel 2. Bentuk kromosom Salak Sidimpuan pada pasangan kromosom homolog

\begin{tabular}{cc}
\hline Pasangan kromosom & Bentuk kromosom \\
\hline 1 & metasentrik $(\mathrm{m})$ \\
\hline 2 & metasentrik $(\mathrm{m})$ \\
\hline 3 & submetasentrik $(\mathrm{sm})$ \\
\hline 4 & metasentrik $(\mathrm{m})$ \\
\hline 5 & metasentrik $(\mathrm{m})$ \\
\hline 6 & mebmetasentrik $(\mathrm{sm})$ \\
\hline 7 & metasentrik $(\mathrm{m})$ \\
\hline 8 & metasentrik $(\mathrm{m})$ \\
\hline 9 & metasentrik $(\mathrm{m})$ \\
\hline 10 & submetasentrik $(\mathrm{sm})$ \\
\hline 11 & metasentrik $(\mathrm{m})$ \\
\hline 12 & submetasentrik $(\mathrm{sm})$ \\
\hline 13 & submetasentrik $(\mathrm{sm})$ \\
\hline 14 &
\end{tabular}




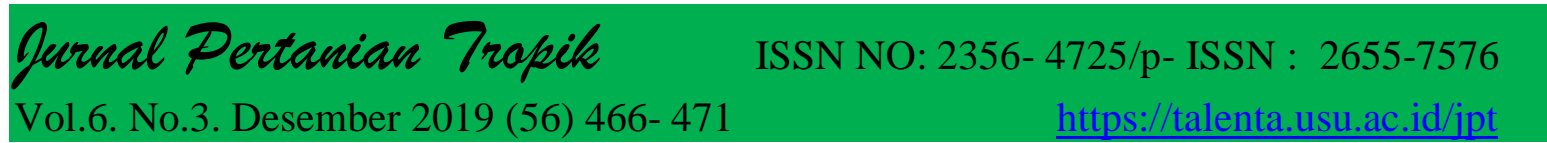

Hasil pengamatan pada salak Sidimpuan menunjukkan bahwa kromosom yang berbentuk metasentrik ditunjukkan pada pasangan kromosom nomor $1,2,4,5,7,8,9,10$ dan 12 sedangkan submetasentrik ditunjukkan pada pasangan kromosom nomor 3, 6, 11, 13 dan 14).

Metasentrik adalah kromoson yang sentromernya membagi lengan kromoson sama panjang sehingga bentuknya seperti huruf V. Submetasentrik adalah kromoson yang letak sentromernya dekat dengan tengah kromosom yang demikian memiliki bentuk seperti huruf L. Kromosom berbentuk metasentrik sangat sering dijumpai pada makhluk hidup terumtama tumbuhan hal ini merupakan wajar karena mengingat kelompok tumbuhan umumnya memiliki kromosom dengan bentuk demikian. Sesuai dengan pernyataan Suminah dkk., (2002), bahwa tumbuhan umumnya memiliki kromosom berbentuk metasentrik.

\section{Kariotipe}

Kariotipe suatu individu pada dasarnya konstan, namun dalam kondisi tertentu dapat terjadi penyimpangan sehingga morfologi kromosomnya berubah. Perubahan tersebut dapat berupa penambahan atau pengurangan bagian kromosom dan penyusunan kembali bagian kromosom (Pramashintha dkk., 2003).

Kariotipe disusun dengan mengatur kromosom secara berurutan dari ukuran terpanjang sampai terpendek serta memasangkan kromosom dengan kromosom homolognya. Pasangan kromosom homolog ditentukan berdasarkan kemiripan ukuran dan kemiripan bentuk rasio lengan kromosom (Haryanto, 2010).

Berdasarkan kemiripan bentuk dan ukuran kromosom dapat diketahui bahwa kromosom salak adalah diploid (2n). Kemiripan bentuk dan ukuran kromosom yang telah disusun dan diurutkan menunjukkan hanya ada 2 kromosom pada tiap pasangan kromosom homolognya (Parjanto dkk., 2003).

Susunan Kariotipe Salak Sidimpuan (Salacca sumatrana Becc.) dapat dilihat pada Gambar 1. berikut.

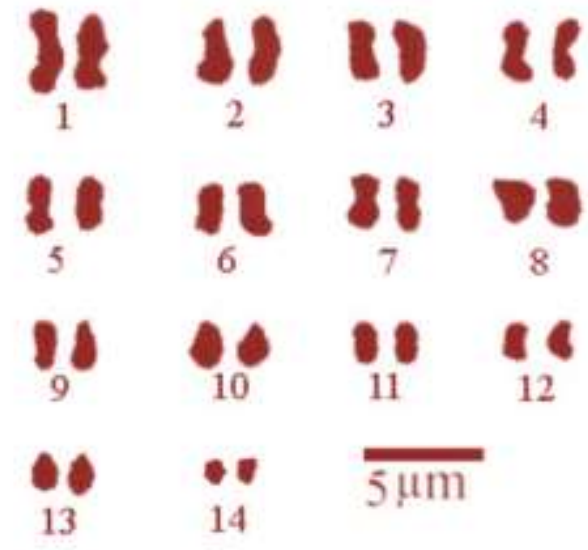

Gambar 1. Kariotipe Salak Sidimpuan (Salacca sumatrana Becc). 


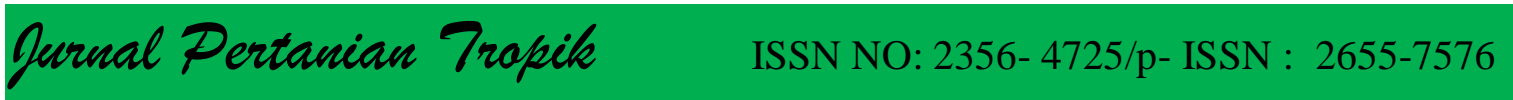

\section{SIMPULAN}

Hasil identifikasi kromosom cangkok anakan Salak Sidimpuan memiliki identitas dengan jumlah kromosom $2 \mathrm{n}=28$, untuk bentuk kromosom Salak Sidimpuan terdapat 9 metasentrik dan5 submetasentrik dan untuk kariotipenya memiliki rumus kariotipe $2 n=9 m+5 s m$.

\section{DAFTAR PUSTAKA}

Badan Pusat Statistik. 2010. Kota Padang Sidimpuan, Badan Pusat Statistik Kota Padang Sidimpuan.

Parjanto, S., Moeljopawiro, W.T., Artama dan Purwantoro, A. 2003. Kariotipe Kromosom Salak. Zuriat. 14 (2) : 21-28.

Pramashintha, F., Purwantoro, A. dan Taryono. 2003. Analisis Kromosom Dalam Penentuan Jenis Kelamin Tanaman Melinjo (Gnetum gnemon L.). Agrosains. 16(1): 17-29.

Pujoarinto, A. 2001. Taksonomi Tumbuhan Tinggi. Jakarta: Pusat Penerbitan Universitas Terbuka

Rindyastuti, R. dan Daryono B.S. 2009. Identifikasi Papasan (Coccinia grandis (L.) voigt) di Tiga Populasi di Yogyakarta. Jurnal Biologi Indonesia. vol 6 (1): 131142.

Setyawan, A. D. dan Sutikno. 2000. Karyotipe Kromosom pada Allium sativum L. (Bawang Putih) dan Pisum Sativum L (Kacang Kapri). BioSmart. 2(1) : 20-27.

Sewoyo, S.A. 2007. Sitogenetika. Yogyakarta: Gadjah mada University Press.
Suminah, Sutarno dan Setyawan, A.D. 2002. Induksi Poliploid Bawang Merah (Allium ascalonicum L.) dengan Pemberian Kolkisin. Biodiversitas. 3(1) : 174-180. 